\title{
JOURNAL.RU
}

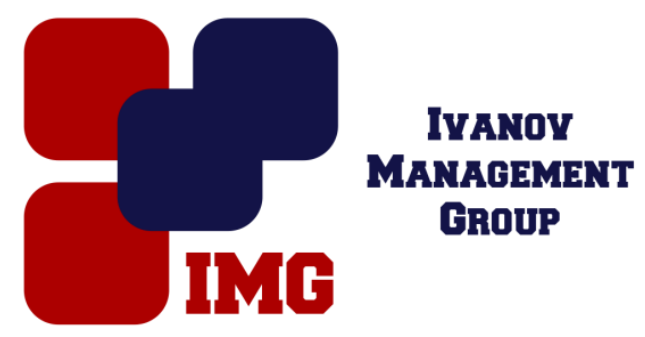

Амурская О.И. Рязанский государственный университет имени С.А. Есенина Рязань, Россия

doi: $10.18411 / 1 \mathrm{j}-31-07-2017-02$

idsp 000001:1j-31-07-2017-02

\section{Роль рекламы и PR в решении проблем информационной безопасности в современных социальных коммуникациях}

\begin{abstract}
Аннотация
В статье рассматриваются проблемы защиты физического, умственного и нравственного развития детей и молодежи, проблемы распространения экстремистских идей в молодежной среде и возможные меры противодействия вербовке молодежи в секты, «группы смерти», группы экстремистского толка с точки зрения различных субъектов, способных осуществлять профилактические мероприятия и осуществлять конкретные меры по повышению информационной безопасности, в том числе средствами рекламы и связей с общественностью.

Ключевые слова: информационная безопасность, реклама, связи с общественностью, меры профилактики, молодежь.

Информационная безопасность в обществе в началу XXI столетия представляет собой актуальную проблему как в научном, так и в управленческом и учебно-воспитательном аспектах. Высокие скорости социальных изменений провоцируют масштабные изменения в социуме, вследствие чего угроза информационной безопасности детей и молодежи выходит на первый план.

Неоднозначность современных проблем, спровоцированных переизбытком информационных потоков, осложняет возможности современной молодежи в реальной оценке их угроз. Присутствие информационных технологий в реальной жизнедеятельности людей и взаимодействие с обществом в виртуальном пространстве, определяют повышенные требования к
\end{abstract}


информации как с профессионально-квалификационной, так и с социальнопсихологической, этической, культурно-нравственной позиций.

Наряду с очевидными тенденциями социального прогресса, трансформация общества вызывает обеспокоенность представителей широкой общественности. Едва ли не в первую очередь данное утверждение касается коммуникационной системы общества начала XXI в. Интернет и компьютерные технологии изменяют не только облик системы массовой коммуникации, но и всего общества в целом. Исследователи все чаще говорят о тенденциях виртуализации социального пространства, замещении реальных взаимодействий симуляционными. В интернет-среду перемещаются и многие не решенные ранее проблемы, не ликвидированные годами угрозы. В итоге наша страна все чаще сталкивается с видоизменившимися и от этого ставшими еще более опасными вызовами информационного терроризма, экстремизма, киберпреступности и т.д.

Становится очевидным, что в современных условиях трансформирующегося общества риска необходимы пересмотр научнотеоретических и управленческих подходов к обеспечению информационной безопасности, их адаптация к быстро меняющимся условиям общественной жизни. В данной сфере выделяется ряд проблем, требующих безотлагательного решения. Это - развитие научно-практических основ информационной безопасности, отвечающей современной геополитической ситуации и условиям политического и социально-экономического развития России; формирование законодательной и нормативно-правовой базы обеспечения информационной безопасности; разработка механизмов реализации прав граждан на информацию и информационную безопасность; формирование системы информационной безопасности, являющейся составной частью общей системы национальной безопасности страны; разработка современных методов аудита безопасности информационной системы, обеспечивающих комплексное решение задач защиты информации; разработка критериев и методов оценки эффективности систем и средств информационной безопасности и их сертификации; исследование форм и способов цивилизованного воздействия государства на формирование общественного сознания. Привлечение средств рекламы и связей с общественностью к решению данного круга проблем представляется перспективным с точки зрения эффективности.

$\mathrm{C}$ точки зрения привлечения именно инструментов рекламы и $\mathrm{PR}$ можно обозначить следующие направления формирования и развития резистентности к негативным влияниям информационных потоков в первую очередь в 
молодежной среде: например, в целях повышения уровня информационной безопасности в современных социальных коммуникациях, развития профессиональных, социальных, управленческих компетенций субъектов информационного взаимодействия, средства рекламы повысят понимание необходимости систематического повышения квалификации или профессиональной переподготовки работников органов государственной власти и управления, используя потенциал рязанских вузов.

Именно средствами связей с общественностью во многом поддерживается практика внедрения принципов и механизмов открытого обсуждения проблем информационной безопасности, предусматривающая прозрачность информационных процессов и их непротиворечивость российскому законодательству, а также широкое использование современных информационных технологий и новых средств коммуникации в осуществлении взаимодействия с молодежью.

Назрела необходимость усиления этического компонента в подаче и размещении материалов в сети Интернет, что следует рассматривать не как административную меру воздействия на средства массовой коммуникации, а как инструмент развития их нравственных характеристик в рамках системы социальных механизмов, действующих в обществе.

Средства рекламы и PR позволят расширить практику обмена опытом по формированию иммунитета к потенциально-опасным группам и сообществам в сети Интернет, между различными направлениями госслужбы, силовых структур, органов исполнительной власти, СМИ, системы образования и религиозных институтов путем организации панельных дискуссий в контексте современных проблем информационной безопасности.

Также, необходимо совершенствование деятельности подразделений информации и общественных связей, пресс-служб ЦИОГВ по взаимодействию со средствами массовой информации, институтами гражданского общества, правовому информированию государственных, муниципальных органов, граждан через СМИ и информационно-телекоммуникационную сеть Интернет, реализация согласованной политики в области создания эффективных механизмов противодействия информационно-манипулятивным атакам на детей и молодежь. 
1. Кононенко Н.С. Суицид как объект социологического исследования // Вестник Краснодарского университета МВД России. - 2015. - № 4(30). - С. 274-277.

2. Кубякин Е.О. Молодежный экстремизм в условиях информатизации и глобализации социума: постановка проблемы // Историческая и социально-образовательная мысль. 2011. № 3. С. 65-69.

3. Магомедов К.О. Проблема нравственности государственных гражданских служащих в социологическом измерении // Мониторинг общественного мнения: экономические и социальные перемены. - 2013. - № 8 (114). - С. 108-113. 